Pamiętnik Literacki 2013, 1, s. 199-205
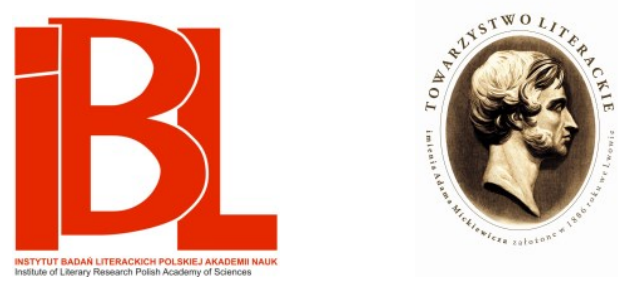

Maria Renata Mayenowa o „Weselu”

Wyspiańskiego

Magdalena Popiel 
MAGDALENA POPIEL

(Uniwersytet Jagielloński, Kraków)

\section{MARIA RENATA MAYENOWA O „WESELU” WYSPIAŃSKIEGO}

Wśród nie publikowanych dotąd pism Marii Renaty Mayenowej znajduje się m.in. jej dysertacja doktorska dotycząca kompozycji Wesela Stanisława Wyspiańskiego. Maszynopis doktoratu (być może, jedyny w Polsce), zatytułowanego „,Wesele" Stanisława Wyspiańskiego. Czesść pierwsza. Problemy kompozycji, przechował w swojej bibliotece prof. Henryk Markiewicz. Otrzymał go od autorki w latach sześćdziesiątych, gdy prowadził na polonistyce w Uniwersytecie Jagiellońskim seminarium magisterskie poświęcone temu właśnie dramatowi. Korzystając z uprzejmości Profesora, który udostępnił mi ów maszynopis, chciałabym przedstawić tę wyjątkową w dorobku Mayenowej analizę młodopolskiego utworu.

Ogólną informację na temat owej dysertacji doktorskiej łatwo znaleźć w słownikach i omówieniach bibliograficznych, nie była ona jednak znana nawet we fragmentach szerszemu gronu czytelników. Zapewne sama autorka stwierdziła po latach, że rozprawa w tej wersji nie nadaje się do druku. Na taką decyzję miały, być może, wpływ dynamicznie zmieniające się okoliczności lat trzydziestych i czterdziestych: tytuł doktora Mayenowa (wówczas Rachela Kapłanowa) otrzymała w maju 1939, promocja odbyła się 13 grudnia tego roku na Uniwersytecie Stefana Batorego w Wilnie, wybuch wojny, dramatyczne losy czasu okupacji, wyjazd do Pragi w 1946 z drugim mężem, Józefem Mayenem, wtedy pracownikiem Ambasady Rzeczypospolitej - te doświadczenia życiowe sprzyjały wytworzeniu się dystansu wobec wczesnego dorobku naukowego. Na pewno nie jest to pełne wyjaśnienie owego zaniechania; zdarzało się wszak nieraz, że teksty naukowe powstałe przed rokiem 1939 szczęśliwie zachowane przez lata zawieruchy wojennej były publikowane po 1945 roku. Niektóre z nich, zachowując świeżość i oryginalność koncepcji, wchodziły do kanonu powojennego literaturoznawstwa (wystarczy przypomnieć Modernizm polski Kazimierza Wyki). Można przypuszczać, że w wypadku rozprawy Mayenowej istniał jeszcze jeden powód powstrzymujący autorkę przed publikacją. Praca o Weselu była w zamierzeniu częścią monografii, tekst przedstawiony jako dysertacja doktorska stanowił pierwszą z planowanych trzech części: był on poświęcony kompozycji, dwie kolejne miały analizować język artystyczny oraz metrykę dramatu. Być może, niechęć do podjęcia tego zadania ponownie i dokończenia projektu naukowego była powodem pozostawienia tekstu „w szufladzie"

1 H. Marki ew ic z (list z 10 X 2011) wskazuje jeszcze dwie inne możliwe przyczyny: 
W biografii naukowej Mayenowej dość zagadkowe jest pojawienie się zainteresowania twórczością Wyspiańskiego. Praca magisterska, zainspirowana prawdopodobnie pasjami romantycznymi Stanisława Pigonia, ówczesnego profesora polonistyki wileńskiej, była zatytułowana Wpływ Słowackiego na poezję polska po $1830 \mathrm{roku}$, a z tematów referatów, jakie badaczka wygłaszała na początku lat trzydziestych, wyłania się bardzo różnorodny obraz problemów i nurtów literackich, które ją interesowały: od epoki Kochanowskiego po Jalu Kurka. Wśród nich znalazł się również Stanisław Wyspiański: w roku akademickim 1933/34 Mayenowa przedstawiła referat Rewizja poglądów na dzieła Wyspiańskiego. Po napisaniu przez nią dysertacji doktorskiej o Weselu twórczość Wyspiańskiego będzie jej dostarczała materiału badawczego i egzemplifikacyjnego w jej pracach teoretycznych, ale nigdy nie stanie się przedmiotem osobnego studium. W Poetyce teoretycznej Mayenowa cytowała i analizowała Wesele w aspekcie problematyki metatekstu, wyrażeń cudzysłowowych oraz stylizacji. Warto jednak przypomnieć, że rozprawa $Z$ zagadnień semantyki form wierszowych rozpoczyna się zdaniem: „Wesele Wyspiańskiego nigdy nie zostało porządnie opisane pod względem organizacji metrycznej” ${ }^{2}$, które można potraktować jako sygnał nurtującej badaczkę myśli o niepełności dotychczasowych analiz dramatu i o potrzebie podjęcia tego wyzwania.

Rozprawa Mayenowej o kompozycji Wesela powstawała pod opieką naukową Manfreda Kridla i inspirująca rola promotora jest w niej dobrze widoczna. Kridl objął Katedrę Historii Literatury Polskiej na Uniwersytecie Stefana Batorego w Wilnie w 1932 roku po powrocie z kilkuletniego pobytu na uniwersytecie w Brukseli. Szybko zgromadził wokół siebie grono zdolnych uczniów, do których, oprócz Mayenowej, należeli m.in. Czesław Zgorzelski, Irena Sławińska, Maria Rzeuska. Mistrz przyciągał ich wyjątkową osobowością oraz propozycją radykalnej zmiany sposobu uprawiania nauki o literaturze ${ }^{3}$. Już w swoim wykładzie inauguracyjnym, zatytułowanym Przełom w metodyce badań literackich, Kridl okazał się stanowczym rzecznikiem badań ergocentrycznych ${ }^{4}$. Okres wileński dla samego Kridla stał się czasem ważnej krystalizacji refleksji teoretycznej i sformułowania zasad metody integralnej. Zawdzięczała ona wiele estetyce niemieckiej i coraz pełniejszej recepcji rosyjskiej szkoły formalnej. Kridl, nie znając języka rosyjskiego, korzystał początkowo z przekładów niemieckich, później także polskich, które pojawiły się w ośrodkach najwcześniej zainteresowanych formalizmem, czyli warszawskim i poznańskim ${ }^{5}$. Zapoznawanie się z podstawowymi pracami rosyjskich formalistów odbywało się w sposób szczególnie intensywny właśnie

\footnotetext{
„Maria Renata Mayenowa po wojnie porzuciła pracę o Weselu może dlatego, że w świetle wiedzy o strukturalizmie czeskim, jaką wtedy zdobyła - praca ta była dla niej metodologicznie już nieaktualna. Przede wszystkim zaś opublikowanie pracy o charakterze formalistycznym było wówczas trudne, z czasem stało się niemożliwe".

2 M. R. M a y e n o w a, Z zagadnień semantyki form wierszowych. W: Studia i rozprawy. Wybór, oprac. A. A x e r, T. D obrzyń s k a. Warszawa 1993, s. 276.

3 M. R. M a y e n o w a pisała na ten temat m.in. w pośmiertnym Wspomnieniu o Manfredzie Kridlu (,Nowa Kultura” 1957, nr 7).

4 M. K r i d l, Przełom w metodyce badań literackich. „Przegląd Współczesny” 1933, nr 130.

5 Zob. m.in. H. M a rk i e w i c z, Recepcja formalizmu rosyjskiego w Polsce. W zb.: Problemy wiedzy o literaturze. Prace dedykowane Stefanowi Żótkiewskiemu. Red. A. Brodzka, M. Hopfinger, J. Lalewicz. Wrocław 1986.
} 
w kręgu wileńskich seminarzystów Kridla. Uczestnicy spotkań przedstawiali teksty rosyjskich badaczy, m.in. Jerzy Putrament referował Teorie metody formalnej Borisa Eichenbauma, a Dina Abramowicz Wstep do poetyki Wiktora Żyrmunskiego. Rachela Górewiczówna (tj. Maria Renata Mayenowa) wygłosiła wówczas referat Zagadnienie motywacji prawdopodobieństwa w utworze ${ }^{6}$. Warto wspomnieć, że już po napisaniu doktoratu Mayenowa opublikowała w „Prawdzie Wileńskiej” w 1941 roku (pod nazwiskiem: Rachela Kapłanowa) dwa artykuły omawiające prace rosyjskich badaczy, przede wszystkim Wiktora Winogradowa o Puszkinie i Lwie Tołstoju?

Wileńscy seminarzyści Manfreda Kridla nie tylko penetrowali obszar rosyjskiej „nowej nauki o literaturze”, ale przede wszystkim sami w przygotowywanych rozprawach doktorskich próbowali ją stosować do wybranych utworów literatury polskiej i europejskiej. Zestaw tematów prac doktorskich powstających w tym okresie wskazuje na przyjęcie klucza genologicznego: Jerzy Putrament pisał o strukturze nowel Bolesława Prusa, Maria Rzeuska o Chłopach Władysława Reymonta, Czesław Zgorzelski o balladach, Irena Sławińska o dramacie francuskim. Projekt analizy kompozycji Wesela przygotowany przez Marię Renatę Mayenową wpisywał się w ów nurt badań ergocentrycznych. Z perspektywy czasu warto zauważyć, że wiele $\mathrm{z}$ tych rozpraw powstających w latach trzydziestych pod opieką autora Wstępu do badań nad dzietem literackim stworzyło podstawy polskiej powojennej wiedzy literaturoznawczej. Z wyjątkiem pracy o Weselu...

Dysertacja doktorska została podzielona na 9 rozdziałów, a te autorka rozbiła na szereg szczegółowych mniejszych części. Owe rozdziały to: 1 . Tekst poboczny, 2. Przestrzeń dramatyczna, 3. Czas dramatyczny, 4. Zdarzenie dramatyczne, 5. Kompozycja aktów i scen, 6. Następstwo scen i ruch tematów, 7. Świat , Wesela”, 8. Świat motywów fantastycznych, 9. Problem jedności dramatycznej. Zasadniczy trzon rozprawy został poprzedzony Rozważaniami wstępnymi, zawierającymi, zgodnie z poetyką gatunku pracy doktorskiej, przedstawienie przedmiotu pracy i jej założenia metodologiczne. Autorka przywołuje tu kilka koncepcji dramatu od Arystotelesa po najbardziej przez nią aprobowaną teorię Władimira Wolkensztejna, stwierdza jednak, że żadna z nich nie stanowi właściwego odniesienia dla tego typu dramatu, jakim jest Wesele. Zakłada więc w punkcie wyjścia „,chaotyczny eklektyzm" metodologiczny, umożliwiający łączenie różnych perspektyw (w praktyce okaże się on dość ograniczony).

$\mathrm{Na}$ wstępie Mayenowa określa swoje stanowisko wobec antynomicznych

6 Wiele cennych materiałów na temat ,szkoły wileńskiej” M. Kridla można znaleźć w artykułach T. B u j n i c k i e g o: Maria Renata Mayenowa i seminarium Manfreda Kridla. W zb.: Obecność. Maria Renata Mayenowa (1908-1988). Red. B. Chodźko, E. Feliksiak, M. Olesiewicz. Białystok 2006; Manfred Kridl i jego „, szkoła formalna”. W: Szkice wileńskie. Rozprawy i eseje. Kraków 2002.

7 W okresie powojennym ukoronowaniem zainteresowań edytorskich i translatorskich formalizmem rosyjskim M. R. M a y e n o w e j było wydanie wspólnie z Z. S a l o n i m tomu Rosyjska szkoła stylistyczna (Warszawa 1970). Interesująco komentuje fascynację badaczki formalizmem M. Gło w i ń s k i (Pani Mayenowa-próba portretu. W zb.: Obecność, s. 25-26): „Pani Mayenowa miała w swej osobowości pewien rys, który zbliżał ją do Przybosia. Obydwoje byli przekonani, że kierunki, za którymi opowiedzieli się w młodych latach, są wiecznie żywe i nieposzlakowanie nowatorskie. Sądziła, podobnie jak Przyboś o awangardzie lat dwudziestych, że ten ruch, który rozpoczął formalizm, nie może być kwestionowany, że jest jedynie wartościowy i że od niego zaczyna się w nauce o literaturze wszelka nowoczesność [...]”. 
tendencji postrzegania dramatu w kategoriach literackich lub teatralnych. Trzeba spojrzeć na podjęcie tej problematyki w kontekście sformułowanej w latach czterdziestych przez Stefanię Skwarczyńską teatralnej i literackiej teorii dramatu. Mayenowej bliskie jest kompromisowe stanowisko Wolkensztejna wyłożone w książce Dramaturgija:

Rzeczywiście dramat - dzieło literackie i dramat-przedstawienie to w istocie swojej dwa nie pokrywające się ze sobą dzieła sztuki. Ale stosunek między nimi zachodzący bynajmniej nie wydaje mi się krzywdzący dla dramatu literackiego. Dramat literacki operuje w takim samym stopniu elementami niedostępnymi scenie, w jakim dramat-przedstawienie elementami niedostępnymi dramatowi literackiemu. Szczególnie wyraźnie występuje ta odmienność właśnie w odniesieniu do dramatu St. Wyspiańskiego, podkreślam, odmienność, nie zubożenie. Bogaty, a bezużyteczny z punktu widzenia reżyserskiego tekst poboczny dramatu Wyspiańskiego jest równie nieprzetłumaczalny, albo lepiej, niejednoznaczny z wartościami teatralnymi, jak wartości teatralne są niejednoznaczne ze słowem. Nie wolno więc mówić o niepełności czy ubóstwie tekstu literackiego w stosunku do jego scenicznej realizacji. Można mówić tylko o odmienności. [s. II-III]

Mayenowa bierze pod uwagę zarówno argumenty teoretyków literatury, jak też świadomość estetyczną artysty. Powołując się na opinię Adama Grzymały-Siedleckiego przypomina, iż sam Wyspiański uznawał scenę za miejsce właściwej i pełnej realizacji dramatu. Przyjmuje jednak za rozstrzygający dla możliwości badania Wesela jako tekstu literackiego fakt ukazania się dramatu w formie publikacji książkowej za zgodą autora:

Skoro [...] dramat został przez autora wydany jako książka przeznaczona do czytania, wolno bez obawy dokonania rabunku na dziele sztuki badać dramat w jego postaci literackiej, zostawiając teatrologom, operującym odpowiednimi, różnymi od czysto literackich metodami, zbadanie dramatu-przedstawienia. [s. III]

Jak widać z toku wywodu, próby negocjacji stanowisk opozycyjnych często prowadzą do ryzykownych z punktu widzenia precyzji naukowej paradoksów. Zajmując się zatem z założenia tylko materią literacką dramatu Mayenowa zaczyna swoją analizę od tekstu pobocznego, który zwykle w szczególny sposób łączył tekst dramatu z jego teatralną realizacją. Uznaje go za integralny składnik utworu, przypisując mu niekiedy znaczenie większe niż tekstowi głównemu. To wysunięcie analizy didaskaliów na plan pierwszy w kompozycyjnym i logicznym porządku rozprawy jest niewątpliwie nie wyrażonym do końca bezpośrednio gestem badacza strukturalisty.

Najbardziej oryginalna na tle wcześniejszej „wyspiańskologii” część rozprawy stanowi wnikliwą analizę zdarzenia dramatycznego oraz aktów i scen utworu. Mayenowa wykazuje tutaj nieprzydatność pojęcia akcji, rozumianej racjonalistycznie i celowościowo, dla charakterystyki kompozycji Wesela. Uważa, że w kompozycji dramatu Wyspiańskiego szczególne miejsce zajmują zasady budowy i porządek scen i aktów. Dystansuje się od tych tradycji badań dramatu (Chmielowski, Siedlecki, Kotarbiński, Flach, Bergel, Makowiecki), które w ujęciu sceny akcentowały wartość liryczną dialogów, stylizację szopkową czy, jak w wypadku książki Makowieckiego, związki ze sztukami plastycznymi. Mayenowa zmierza przede wszystkim do stworzenia formalistycznego opisu scen dramatu, ujawniając prawidłowości ich konstrukcji. Przeprowadza rozróżnienie na sceny centralne i przejściowe, samodzielne i sceny-łączniki, zamknięte i otwarte, zwraca uwagę na 
osłabioną delimitację aktów. Przedstawia też analizy statystyczne dotyczące liczby osób występujących w kolejnych scenach.

Istotnym przedmiotem opisu są czynniki wpływające na odmienność strukturalną poszczególnych scen. Badaczka analizuje pod tym względem rolę światła, muzyki, a także mimiki i ruchu postaci. Pojawiają się w tym kontekście przywołania dramaturgii przełomu XIX i XX wieku, przede wszystkim Maeterlincka, D’Annunzia, Wilde'a. Ważną rolę w konstytuowaniu się całości sceny ma typ dialogu, który okazuje się dominującym wyznacznikiem kompozycji. Analiza walorów rytmiczno-dźwiękowych dialogu prowadzi do podjęcia wątku stylizacji: w rozdziałach 5 i 6 mowa o scenach przypominających „numery rewiowe” czy szopkowe, a w wypadku scen zbiorowych - formy operowe, pieśniowe.

Ta zasadnicza część rozprawy, analizująca kompozycję dramatu, zmierza do uargumentowania tezy przewijającej się w całej pracy: Wesele jest dla Mayenowej efektem procesu rozpadu dramatu klasycznego, procesu, który dokonał się nie tyle za sprawą „destrukcyjnej siły” poetyki romantycznej, co przede wszystkim dzięki przemianom dramatu realistycznego w drugiej połowie XIX wieku. Przełamywanie się realizmu, wchłaniającego różne obce pierwiastki i nurty, dostrzega Mayenowa w twórczości takich dramaturgów europejskich, jak Ibsen, Hauptman, Czechow czy Andriejew. Analiza konstrukcji przestrzeni i czasu przeprowadzona w rozdziałach 2 i 3 ma na celu oderwanie refleksji nad tymi czynnikami kompozycji Wesela od tradycyjnie pojmowanych kategorii jedności czasu i miejsca, którymi, zdaniem autorki, błędnie posługiwali się wcześniejsi interpretatorzy Wyspiańskiego. Ściśle ze sobą połączone wymiary temporalne i spacjalne utworu prowadzą do swoistej koncentracji dramatycznej i semantycznej tekstu, efekt ten zostaje osiągnięty jednak innymi środkami niż w dramacie przedromantycznym. Zabiegi zmierzające do modyfikacji dramatu realistycznego w Weselu bada Mayenowa w różnych obszarach tekstu. Zgadzając się zasadniczo na interpretację szopkową (przywołuje tu głównie artykuły Antoniego Potockiego), podkreśla również mocno marionetkowość postaci i osadza tę tendencję w inwencji teatralnej Gordona Craiga:

w budowie postaci, jak i we wszystkich innych elementach kompozycji, tradycja realistyczna została chwycona w tryby zupełnie jej przeciwne, tryby marionetkowej stylizacji. [s. 161]

Analiza bohaterów dramatu zawarta w rozdziale 7 dobrze pokazuje nowy typ wrażliwości literackiej, który Mayenowa zawdzięcza, jak można przypuszczać, lekturze formalistów rosyjskich. Chodzi o postrzeganie świata poetyckiego przede wszystkim poprzez zestaw operacji dokonywanych na materiale literackim. A zatem ,świat Wesela" to głównie świat tekstowy, budowany w procesie ciągłego przetwarzania innych dzieł literackich. Metoda charakterystyki postaci waha się między wskazaniem genezy bohaterów a intertekstualnymi procedurami interpretacyjnymi.

Tego typu obserwacje jeszcze bardziej komplikują obraz utworu realistycznego, który czyni Mayenowa tak ważnym punktem odniesienia. Stopień trudności jeszcze się podnosi, gdy autorka próbuje zobaczyć dramat Wyspiańskiego w perspektywie tragizmu. Wykluczając możliwość zastosowania tej kategorii w ujęciu Maxa Schelera, stwierdza:

Trzeba jednak przyznać, że traktujący groteskowo swoje postaci dramat wytwarza nie tylko pewną wszechogarniającą aurę tragizmu, płynącą z zaprzepaszczenia szlachetnego pory- 
wu, wytwarza także atmosferę tragizmu naokoło poszczególnych osób. Tragizm to bardzo specjalnego gatunku, ogromnie typowego dla epoki, tragizm najzupełniej oderwany od podłoża faktycznego, tragizm poczucia niemożności realizacji wzniosłych marzeń, zresztą również niekonkretnych, tragizm postaci Przybyszewskiego, Berenta, Brzozowskiego i innych. [s. 163]

Z wywodów autorki wyłania się dość nieprecyzyjnie określona, ale wyrazista potrzeba przeformułowania i przewartościowania pewnych kluczowych pojęć literackich i estetycznych. Ten aspekt dyskursu analityczno-interpretacyjnego Mayenowej jest jednym z cenniejszych rysów młodzieńczej rozprawy.

Praca Marii Renaty Mayenowej stanowi dowód świadomej decyzji wyboru drogi interpretacji Wesela zasadniczo odmiennej od tych, które dominowały w lekturze krytycznej tego utworu przez prawie cztery dekady. Nie jest to spojrzenie ideologiczne, które w odczytaniach Wesela jako dramatu narodowego odgrywało tak ważną rolę już od czasu pierwszych recenzji po premierze w 1901 roku. Badaczka, idąc śladami swego mistrza, Manfreda Kridla, nie korzysta również z możliwości, jakie stwarzała psychologia w wariancie tak XIX-, jak i XX-wiecznym. Nie jest to także droga analizy estetycznej w rodzaju tej zaproponowanej chociażby przez Stefana Kołaczkowskiego w latach dwudziestych ubiegłego wieku. Szczególnie ciekawe jest polemiczne nastawienie do bliskiej chronologicznie (1935 rok) książki Tadeusza Makowieckiego o Wyspiańskim ${ }^{8}$, będącej jego pracą habilitacyjną. Zarówno Kridl, jak i Mayenowa eliminują z kręgu swoich zainteresowań ten rodzaj estetyzmu czy perspektywy komparatystycznej w badaniach literackich, który wykracza poza kompetencje czysto literaturoznawcze. We Wstępie do badań nad dzietem literackim pisze Kridl:

Jako nauka o sztuce w ogóle, o przedmiotach estetycznych, [estetyka] posiadać musi obok swoich własnych zagadnień wiele punktów stycznych z nauką o literaturze. Przy formułowaniu więc pojęć ogólnych, takich jak harmonia, proporcja, rozmiary i ich znaczenie strukturalne, wzniosłość, tragizm, wdzięk, komizm itp., musimy się, choćby częściowo, opierać na wynikach estetyki. Częściowo - gdyż trzeba nam zawsze pamiętać o odrębności literatury od innych rodzajów sztuki, o jej specyficznych środkach i sposobach wywoływania podobnych efektów. Niezdawanie sobie sprawy z tych podstawowych różnic, np. że co innego jest krajobraz w malarstwie, a co innego w poezji, że inna zupełnie jest „,melodyka” w muzyce, a inna w języku poetyckim i wierszu, że nie można identyfikować takich pojęć, jak perspektywa, tło, ruch itp. w plastyce i w literaturze, że więc i związki pomiędzy tymi dziedzinami są luźne, a wszelkie próby „wyjaśniania” jednych przez drugie muszą tym samym chybiać - niezdawanie sobie sprawy z tego wszystkiego doprowadza do wielu nieporozumień i nieodpowiedniego stawiania zagadnień czysto literackich (cała ,szkoła” Wolfflina, u nas ostatnio, świetna poza tym książka Makowieckiego o Wyspiańskim) ${ }^{9}$.

Postrzegana w kontekście wachlarza odrzuconych możliwości interpretacyjnych mocno już ugruntowanych w polskiej historii literatury rozprawa Mayenowej zyskuje walor nowatorstwa. Mimo widocznej nieporadności warsztatowej charakterystycznej dla początkującego badacza, a także pewnej niestaranności wykończenia jest ona tekstem godnym przypomnienia. Pozostaje otwarte pytanie o brak w lekturach autorki omawianej rozprawy doktorskiej opracowań twórczości Wyspiańskiego, których ranga w tych pierwszych czterech dekadach recepcji była już

8 T. M a k o w i e c k i, Poeta-malarz. Studium o Stanisławie Wyspiańskim. Warszawa 1935.

9 M. K r i d l, Wstęp do badań nad dziełem literackim. W zb.: Teoria badań literackich $w$ Polsce. Wypisy. Oprac. H. M a r k i e w i c z. T. 2. Kraków 1960, s. 125. 
znaczna, np. Lacka, Brzozowskiego, Boya-Żeleńskiego, Trojanowskiego, Balka czy Kolbuszewskiego. Odpowiedź na to pytanie musiałaby paść dopiero po zbadaniu archiwów biblioteki uniwersyteckiej w Wilnie i zapewne zaprowadziłaby nas na teren preferencji literackich i erudycji promotora dysertacji.

W roku 2007 dzięki Wydawnictwu „Universitas” otrzymaliśmy nie znany dotąd portret Wyspiańskiego nakreślony przed prawie 40 laty przez Jana Błońskiego ${ }^{10}$. Ważną częścią tego obrazu twórczości Wyspiańskiego przygotowanego dla Francuzów - słuchaczy wykładów Błońskiego w Clermont-Ferrand, była narracja o Weselu. Do tego nieustannie rozrastającego się w różnych kierunkach, ciągle pulsującego życiem wyjątkowego dramatu Wyspiańskiego warto dorzucić jeszcze jedną nić snutą pod inną szerokością geograficzną i w innym punkcie czasu w Wilnie lat trzydziestych XX wieku.

\author{
Abstract \\ MAGDALENA POPIEL \\ (Jagiellonian University of Cracow)

\section{MARIA RENATA MAYENOWA \\ ON STANISŁAW WYSPIAŃSKI'S “WESELE” (“THE WEDDING”)}

The article is devoted to a presentation of so far unknown to a wider public of Polish scholars doctoral dissertation ,Wesele” Stanisława Wyspiańskiego. Problemy kompozycji (Stanisław Wyspiański's ,, The Wedding." Problems of Composition) by Maria Renata Mayenowa. The dissertation, typewritten to date, was composed under supervision of Manfred Kridl in 1932 at Stephen Batory Vilnius University. The author of the article sets the dissertation against the then dominating methodological tendencies, and points out both original and derivative features of Mayenowa's interpretation.

${ }^{10}$ J. B łoń ski, Wyspiański wielokrotnie. Oprac. i red. M. B orowski, M. Sugiera. Wykłady z języka francuskiego przeł. J. i K. B ł o ń s c y. Kraków 2007. 